\title{
GEOGRAPHY, POVERTY AND DEVELOPMENT: AN INTERDISCIPLINARY DEBATE
}

\author{
Geografia, pobreza e desenvolvimento: um debate interdisciplinar
}

\author{
Anand Prasad Mishra \\ Associate professor, department of geography, Faculty of science \\ Banaras Hindu University. \\ Varanasi 221005 - Uttar Pradesh - India \\ adeepayan@yahoo.com \\ adeepayan@gmail.com
}

Artigo recebido para publicação em 20/02/2011e aceito para publicação em 20/06/2011

\begin{abstract}
An emerging feature of contemporary development studies in India is the deployment of an interdisciplinary approach involving geographical location, level of poverty, nature of development and planning etc. The prevalence of poverty in a specific geographical location represents the evolving pattern of deprivation under a particular mode of production. The historicity of poverty in a geographical space needs an independent enquiry and identification of different production systems which are responsible for the problem of deprivation through multiple routes. The present paper is an attempt to initiate a debate on the issue of poverty, especially in a tribal region, through a multi-dimensional perspective, i.e. interrelation between geography, poverty, development and planning. The paper identifies one of the most poverty-stricken regions of India for a detailed discussion of the various casual factors which are apparently responsible for the poverty of that region. The paper also tries to explore the historical background of poverty in the study area (Babhani Block of Sonbhadra U. P.).
\end{abstract}

Keywords: Poverty. Deprivation. Geography of poverty. Historical routes of poverty.

RESUMO: Uma característica emergente dos estudos de desenvolvimento na Índia contemporânea éa implantação de uma abordagem interdisciplinar envolvendo localização geográfica, nível de pobreza, a natureza do desenvolvimento e planejamento, entre outros. A prevalência da pobreza em um local geográfico específico representa o padrão evolutivo de privação em um modo particular de produção. A historicidade da pobreza em um espaço geográfico precisa de um inquérito independente e identificação de diferentes sistemas de produção que são responsáveis pelo problema de privação através de várias rotas. O presente trabalho é uma tentativa de iniciar um debate sobre a questão da pobreza, especialmente em uma região tribal, através de uma perspectiva multi-dimensional, ou seja, de inter-relação entre a geografia, a pobreza, desenvolvimento e planejamento. O documento identifica uma das regiões mais atingidas pela pobreza da Índia para uma discussão detalhada dos diversos fatores casuais que são aparentemente responsáveis pela pobreza da região. O documento também tenta explorar o fundo histórico da pobreza na área de estudo (Babhani Bloco da UP Sonbhadra).

Palavras-chave: Pobreza. Privação. Geografia da pobreza. Rotas históricas da pobreza. 


\section{INTRODUCTION}

The interdisciplinary approaches to geography, poverty and development are now becoming major issues in the discourses of development studies. Geographical regions combined with development policies reflect the nature of prosperity and poverty. The complexity of geography and developmental strategies creates the nature of poverty. On this account, poverty is multidimensional and it should be analysed on the basis of multi-disciplinary approaches i.e. geographical, economic, political, etc. Considering the various aspects of poverty there is a need for a multidimensional poverty index (MDPI) which may be helpful in scientific studies. Recently, the geography of region, especially tribal and hilly regions, has induced policy makers to incorporate the ground reality of space while framing suitable development strategies. Also the geography of a particular society and an individual's location in that geography plays a major role in their level of development. The experiences of Indian Naxal movement highlight the reality of deprivation and its relation to space and development policy. Although various theses on the problem of poverty have been discussed and debated by academia and policy makers, i.e. decision making, structural, vicious circle of poverty, market, cultural aspects of poverty, etc., and these have produced new and rich insights pertaining to the phenomenon of poverty, the geographical space in its historical context reveals an entirely different scenario on the interrelation between poverty and development. This has initiated a search for new paradigms for social sciences and development studies. Poverty is not a simple problem of arithmetic but it originates from multiple causes. Geography alone cannot account for the phenomenon of deprivation in a particular region; its interactive impact on development has vital interest for studies.

The evolutionary processes of geographical space represent various accumulative knowledges, developments and deprivations in its socio-economic imprints. These are valuable components for studying the nature of poverty-stricken regions. The extent and nature of poverty cannot be understood only in terms of the present be unless its historical routes are analytically identified. Many believe that poverty starts with the individual or the group due to demerits in their process of development. It called the vicious circle of poverty. But this approach in many ways hides the facts responsible for the origin of poverty in particular historical periods. In view of such faulty and lap-sided approach, a rational methodology is required to formulate systematic guide lines for discourses on poverty, development and its relation to geographical space.

\section{GEOGRAPHY OF POVERTY}

The spatial pattern of poverty in its historical sequence requires the geographical interpretation with the dialectical awareness of a researcher. "The phenomenon associated in a particular place is unsystematically related because they are produced by different processes, [the geographer's] particular mission is to study each process as it operates in particular places, and as it is actually modified in its action by the presence of other unsystematically related phenomenon grouped naturally together on the face of earth" (JAMES, 1952). The nature and distribution pattern of poverty includes many facets of the geographical component and in a way explains the linkages between the terrain of a region and the magnitude of poverty. It reveals the complexity of poverty generated in a specific area. To explain this material condition of pauperization, geographical explanation to some extent is necessary. In this context the geographical knowledge incorporated by Hartshorne may prove its utility in understanding the problem. He observed, "geography seeks to acquire a complex knowledge of the areal differentiation of the world....Phenomena significant to areal differentiation have a real expression.....Consequently, in studying the interrelation of these phenomenon, geography depends first and fundamentally on the comparison..[Geographically complex element] is significant, is studied in terms of its relation to the total differentiation of areas." (HARTSHORNE, 1939). Geographers study the geo-phenomenon in its different historical stages and also demarcate its extent and magnitude in affecting human ecology. On this account, geographical tools for poverty analysis are better suited to estimate and evaluate the situation of hunger and deprivation spread over various regions. 
Poverty in India has many dimensions in its structure and nature of severeness. Broadly, the poverty landscape in various geographical areas has originated from the process of interaction between people, social formation and the nature of political economy. To conceptualize these aspects in a scientific framework is difficult and complex. However, the prevalence of acute poverty in 7 districts of India needs a detailed analysis in order to explain the problems of deprivation and marginalization. Dutta and Sharma (2000) tried to demarcate the 7 most deprived and severe poverty stricken regions of India. These regions lay in backward, underdeveloped states of Bihar, Madhya Pradesh, Uttar Pradesh and Rajasthan. Geographically, most of the regions are characterized by a homogenous pattern of landscape i.e. land, soil, forest and water. The poverty in these regions has the same mechanism and dynamics to its surroundings. Table 1 reveals the spatial pattern of poverty in India, its severeness in most of the plateau areas with rough terrains and brings out its magnitudes in statistical form, thus explaining the problems of deprivation in a scientific way.

The Kalahandi region of Orissa is characterized by extreme poverty ( 69.02 per cent) with low level of literacy (23.56) and high level of infant mortality (137 ).This southern part of Orissa is very much prominent in the poverty ( 34.08 per cent severely poor) atlas of India. Northern Bihar too reveals high level of poverty. Kishanganj is one of the most deprived parts of India, which has more than 58 per cent of population living in severe poverty condition. The female literacy rate in Kishanganj is only 10 per cent and infant mortality is the highest in state, i.e.at 113. The South West regions of Madhya Pradesh (geographically the Vindhya plateau) have the proportion of rural poor more than 68 per cent. Geographically it covers some parts of Uttar Pradesh also. The eastern part of Uttar Pradesh, due to its geographical location, reveals severe condition of deprivation (48.6 per cent poor and 23.2 per cent severely poor) in the district of Bahraich. In the same way the western part of Uttar Pradesh also has a poverty stricken region in Budaun district where more than 40 per cent of the rural population led a life of misery and deprivation. Rajasthan is another geographical part of India where large proportion of rural population is under the category of poverty. More than 30 per cent of this population suffers from severe poverty condition.

Table 1: Poverty Level in 7 Most Deprived Districts of India

\begin{tabular}{c|c|c|c|c|c|c}
\hline STATE & Region & Districts & $\begin{array}{c}\text { Rural } \\
\text { population } \\
\text { poor (\%) }\end{array}$ & $\begin{array}{c}\text { Rural \% } \\
\text { population } \\
\text { severely poor }\end{array}$ & $\begin{array}{c}\text { Urban \% } \\
\text { population } \\
\text { poor }\end{array}$ & $\begin{array}{c}\text { Urban \% } \\
\text { population } \\
\text { severely } \\
\text { poor }\end{array}$ \\
\hline Orissa & Southern & Kalahandi & 69.02 & 34.08 & 45.64 & 33.53 \\
\hline Bihar & Northern & Kishanganj & 58.68 & 27.62 & 49.37 & 21.68 \\
\hline Madhya Pradesh & Central & Damoh & 50.13 & 21.78 & 53.68 & 32.93 \\
\hline Madhya Pradesh & Vindhya & Shahdol & 36.71 & 13.8 & 50.45 & 24.32 \\
\hline Uttar Pradesh & Eastern & Bahraich & 48.6 & 23.2 & 38.6 & 18.48 \\
\hline Uttar Pradesh & Western & Budaun & 29.59 & 10.24 & 31.03 & 14.37 \\
\hline Rajsthan & Western & Barmer & 25.48 & 5.84 & 23.68 & 7.43 \\
\hline
\end{tabular}

Source: Based on Datta, K.L. and Sharma Savita, Level of Living in India, Planning Commission, 2000 
The above discussion underlines the role of geographical location in perpetuating the problems of poverty. All the regions of the 7 most deprived districts have more or less similar geographical features in terms of location, soil quality, water reserves, economic activities and their cumulative effects on the quality of human life. The spatial pattern of poverty needs conceptual interpretation. Writing about the deprived masses, Gramsci observes: "the phenomenon of the masses...is nothing but the form taken by this 'rationalized' society in which the structure dominates the superstructures more immediately and in which the latter are also rationalized" (GRAMSCI, 1971). Santos says, "modes of production write history in time; social formations write it in space ". (SANTOS 1977). Thus the geographical location of a region is the result of interaction of built forms from the past, social relations and natural factors and all of them significantly contribute to and determine the resource building capacity of that region.

The poverty landscape of different geographical areas can be elaborated on the basis of location, process of historical materialism, and natural and social resources endowment. The poverty of the seven most deprived districts can be countered through comprehensive developmental activities of various geographic components which prevail in these regions. Moreover, each element for poverty requires in-depth analysis in light of its space and development. The present paper is an effort to apply these parameters in conceptualizing and analyzing the problem of poverty in the selected regions.

\section{CASE STUDY:}

The plateau regions of Madhya Pradesh, Uttar Pradesh, Bihar, Chhattisgarh, Jharkhand and other parts of central India betray similar reasons for the predominance of poverty among the masses. Though the occurrence of poverty is an outcome of the combined effect of geography and faulty strategies of planning and development, its more multiple reasons may be ignored by a scholar of development studies. However, the manifestation of poverty in specific regions explains the geographical space as a causal factor for deprivation. In the present paper the author will try to analyse the nature of poverty in the plateau and tribal dominated area. As a case study, Babhani Block of Sonbhadra district of Uttar Pradesh has been selected (Figure 1). The area is spread over approximately 6,788 sq. $\mathrm{Km}$. It has 1078 sq. $\mathrm{Km}$. dense forest and $1369 \mathrm{sq}$. Km. open forest. The forest covers is 36.05 per cent of the total geographical area. During of 1981-91 and 1991-2001, a high decadal population growth was registered and it was 38.18 per cent and 36.13 per cent respectively for the two decades. The increasing pattern of population to some extent occurred due to industrial development and diversification in employment structure. The local resources i.e. forest, minerals, stone, timber, red sand etc. attracted the people from outside to settle there.

The study area with distinct geographical features became a zone of tribal/ scheduled caste population. Previously, most of the tribal population was listed as scheduled caste categories and they were deprived of the benefits of state sponsored tribal welfare schemes. In 2003, about 1,00,000 persons were declared as tribal through Uttar Pradesh government notification. The tribal people of the region traditionally secure their employment, livelihood, and habitat from the local forest, water, land and other available resources of nature. The genesis of poverty in this specific region can be explained in terms of different parameters based on its history, socio-cultural organization, pattern of economic development and the level of participation of the local population in decision making processes. For this purpose 10 sample villages of Babhani block were selected and studied.

The table 2 reveals the nature and magnitude of poverty on the basis of sample survey of 10 villages. The tables present the different levels of poverty among the segment of population below poverty line. The average BPL (Below Poverty Line) population for Babhani block is about 74.00 per cent. But the exact level of poverty varies from severe destitute (12.65 per cent) to just below poverty line (9.98 per cent). This emerging socio- economic dimension of the study area turns into a space of contradiction. The micro level study shows the pattern of poverty for specific regions which requires explanation pertaining to its location, development goal and strategies for planning. 


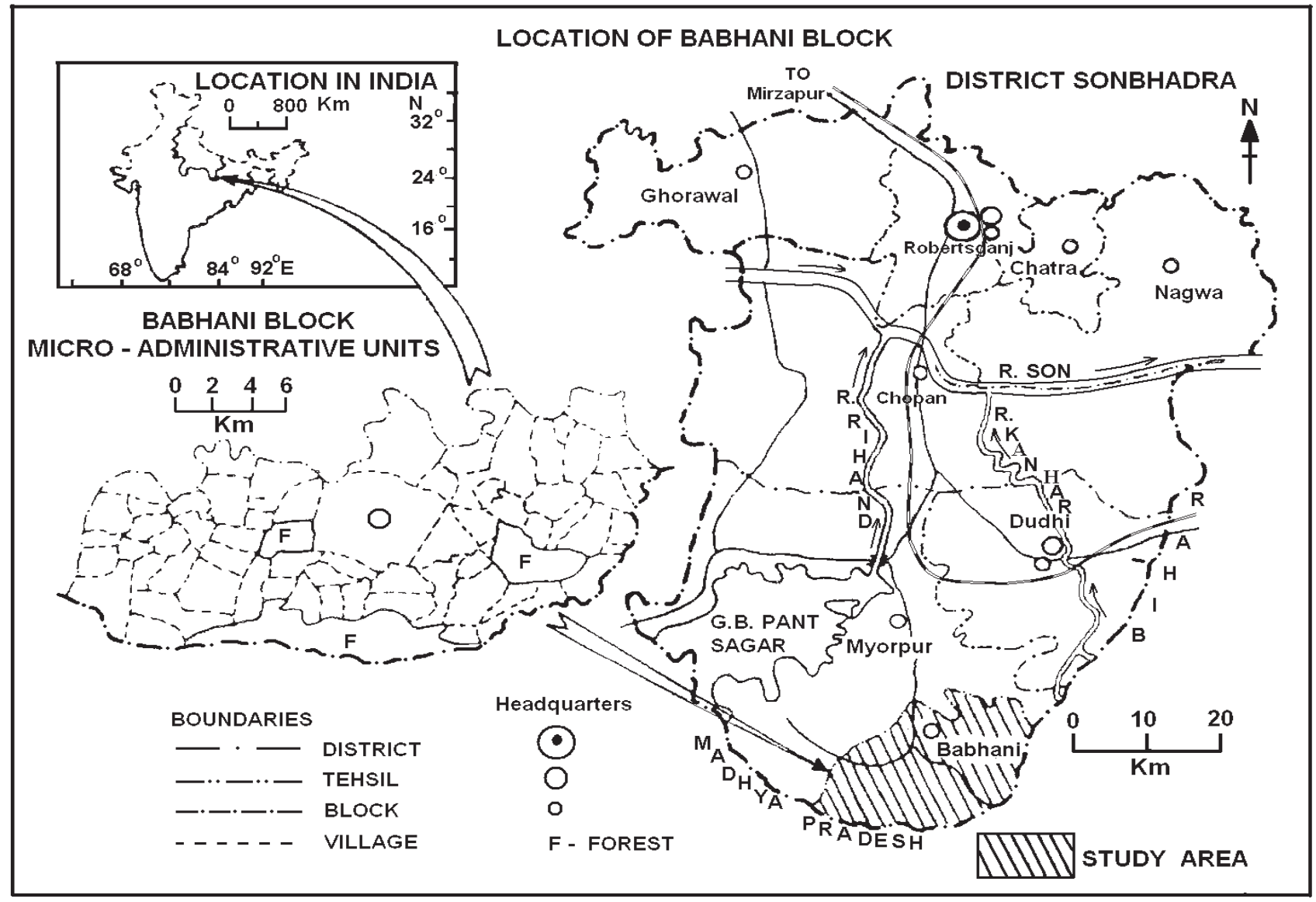

\section{GEOGRAPHY, DEVELOPMENT AND PLANNING}

The nature of poverty and its structure follows the pattern of geography, development and planning, which hinges on the interaction of national policies with local space. Soja considers that,

the structure of organized space is not a separate structure with its own autonomous laws of construction and transformation, nor is it simply an expression of the class structure emerging from the social (i.e. aspatial) relations of production. It represents, instead, a dialectically defined component of general relations of production, relations which are simultaneously social and spatial (SOJA, 1980, p. 208).
In this context, the poverty of a particular space is an outcome of the productive process which depends on the material condition of the area. Therefore, poverty should be investigated in terms of the historical and material background prevailing in spatio-temporal forms in developing world.

Kurien (1982) chose the Marxist approach to explain poverty. According to him it demonstrates that historical forces result in the use of resources being divided almost exclusively by the ownership of resources, and that some stages of history are characterized by society being divided into those who own and use resources on the one hand, and those who do not own resources and hence are used by former. In this context Marxist analysis comes closer to the problem of poverty than does liberal analysis (KURIEN, 1982). However, social scientists have expressed their disagreement on the issue. They have explored the com- 
ponent of poverty as follows: institutions (Durkheim), individuals (Radeliffe-Brown) roles (Talcott Parsons) classes (MARX). (DESHPANDE, V.N. 1992, p. 123). Poverty in an integrated way may be considered as a phenomenon which occurs through individuals, institutions and classes. The process of interaction between individuals, institutions and classes to a very large extent determines prosperity or poverty. And in any discussion of a phenomenon which has its roots in this complex relationship has of necessity, to be alive to the social, economic and cultural practices obtaining in a particular geographical space. Developmental strategies cannot succeed by separating these components, especially when targeting the phenomenon of poverty which is as much geographical and economic as it is social and cultural. This is significantly borne out by the conditions prevailing in the area under study where whatever developmental programmes were set in motion have not produced the desired results chiefly because these programmes were conceived and implemented without necessary assessment of the complex nature of poverty and focusing almost exclusively on its economic aspect.

Geographical space represents the real output of production of nature in a specific region. The spatial production has an impact on social, economic and cultural spheres of life and this impact may be understood in terms of the historical articulation of several mode of production in different periods of history. Certainly, poverty is a product of space through various modes of production under the dynamics of development process. The spatial context of poverty in Babhani block should be considered as an important factor and it should be linked with the production process of this area.

The history and the material condition (historical- materialism) of study area have actual derivational information as regards the trajectory of the changing pattern of mode of production which has close relation with the poverty of the deprived section and prosperity of the masters of productive assets. The chronological sequences starts with the rough terrain, non-availability of good soil and plane area, and the dense forest leading to the total dependency of the tribal population and their un-documented rights and claims on forest and other cognate resources. In the primitive mode of production the residing population of all sections experienced the same nature and extent of absolute poverty. However, this homogeneous character of poverty became a territorial identity of tribals in the specific region. In this context geographical location played a significant role in the manifestations and perpetuation of mass deprivation and poverty.

Geographical location is responsible for the prevalence of poverty and its severeness among different sections of people. The severe poverty conditions of the overwhelming number of tribals (73.72 per cent) owes to multiple factors but the geographical factors have played the most significant role in this regard and have impacted the efforts of modernization developmental plans and projects. The isolation of tribals and other deprived sections is the outcome of the geography of the region. The concentration of destitute categories of poverty (more than 50 per cent) in certain localities and pockets of social groups is closely associated with the history of settlement on the specific area and the emerging pattern of development strategies. The 10 villages selected for the present study constitute the most deprived and poverty-stricken geographical segment of the block. The spatial location of these villages is as much responsible for their abject poverty as the faulty development plans initiated in the area.

The development in an area and its people is based on, the availability of scientific knowledge accumulating over a long period of time in society and community and this cumulative knowledge to a large extent influences the nature and level of development. The nature of economic activity depends on the availability and effectiveness of this knowledge. This is also responsible for the prosperity or poverty of a region before the outset of modern development strategies. Further, the success of modern development strategies depends on the level of participations of the target social groups in the decision-making process. The lower the participation in decision-making, the greater is the likelihood that negative externalities arise; state action can thus become the source of real or potential conflict and any developmental action plans must be devised to resolve or avoid conflicts (COX; REYNOLDS, 1974). The neo-colonial impacts on planning and development always tend to keep the people from the 
process of planning and decision-making and thereby lose sight of the people's initiative for innovation of scientific methodology for development. Reade (1983) aptly says that the "planner's ideology is a major factor in pursuing the path of development" and goes on to observe that "to promote planning is indeed to take an ideological stand because doing so implies a preference over such methods of determining resource allocation and other component of development." In most of the agrarian economy neo colonial and capitalist intervention was occurred and it diverted the genuine path of development. The above mentioned debate on the issues of development is very much significant in order to explain the poverty of study area.

The area is a part of the region which is called 'the power capital of India'. The heavy investment in recent decades in the sectors of thermal power generation, coal mines, aluminum plants ,cement industry, sand and stone crushing, etc. has made possible the optimum exploitation the resources of the region. Prior to such modern industrial activities, the region was primarily a tribal belt with little or no development. The induction of modern inputs like capital, technology and skilled labour has led to development induced displacement and inequality. The local people with the predominance of Human Poverty Index (low life expectancy, knowledge and comfort level) and low status of skilled labour have been rendered unfit to participate in modern productive system and consequently deprived of the traditional resources such as sources of their livelihood and their traditional resource base. Thus the introduction of technology and investment capital has to only aggravate the poverty of the local populace of (table 2\&3). Mishra (2008) extensively analyzed the impact of development induced displacement and its impacts on traditional agrarian economy leading to multiple structures of deprivation and poverty.

In a capitalist productive system any changes in the process of up gradation ultimately create anarchy in societies and its organizations. In this system, "manufacturing process is carried out by isolated private commodity producers who work for an unorganized market and have little idea as to society's actual need for their goods and the scope of production of each commodity in the country as a whole. The anarchy of production is accompanied by competition between commodity producers. Under the capitalist mode of production, anarchy combined with competition spontaneously stimulates the growth of production irrespective of the effective demand of the population. During the transition from the simple commodity economy to the capitalist economy, whose features are a large scale commodity production, a highly developed social division of labour, the growth of labour productivity, establishment of a single domestic market and as a result, the development of social character of production, anarchy assumes enormous dimensions, its destructive force greatly increases, causing economic cataclysms and disruption in the very course of social production" ( VOLKOV, M.L. 1985).

The prevalence of poverty in the study area has its history in the context of changes in the modes of production and consequential process of deprivation. The area in its primitive stage is characterized by primitive agrarian mode of production which was unable to exploit the existing resource potential of the region. After independence the area was considered a suitable geographical location for industrialisation with the availability of minerals and other resources which favored the establishment of modern industrial projects. This has consequential impact on local people and their socio- cultural fabrics and due to this substantial proportion of unskilled population of region has become victims of deprivation. The area is abuzz in the process of transformation from the agrarian to industrial, leaving in its trail acute poverty and misery.

The sequence of poverty in different periods confirms its association with the level of participation, practices in resource utilization and development strategies. Prior to independence the area was untouched by industrialization and modernization; it was only in the post-independent period that its resource potential attracted policy makers and industrialists to develop the region as an industrial hub. At the beginning of $12^{\text {th }}$ century, tribals of this region had attained adequate adjustment with natural resources and developed collective responsibility and incipient cultivation through the Dahiya system of agriculture. During the British period these systems was stopped and settled agricul- 
ture was developed (District Gazetters, Mirzapur District, v. 21). After independence, the Rihand dam came into existence through state sponsored heavy capital investment. Other developmental projects were also started and thus began the process of modernisation and industrialization of the area. A series of public and private industrial projects such as Hindalco and Kanoria Chemicals at Renukoot, Cement industry of Dala, Power plants at Obra, Anpara ,Renusagar and Shaktinagar and hydro-thermal power plant at Pipri came into existence. However, this development has brought in the associated ills of environmental pollution, resource degradation, health hazards, loss of wild life and natural vegetations especially forest and often aesthetic blight (Chandra Shekhar Kumar, 1998)

The presence of modern industrial activities the consequent and diversification in the local economy have had an adverse impact on the tribal population because the tribal have been deprived of their nature-dependent lives and their traditional skills have gave a begging in the face of the new skills and work styles required by modern industries. The changes in mode of production at every step have displaced people from their traditional livelihood and this economic dynamics has generated poverty and deprivation in region. On this account, the study of poverty in this area is no longer a matter of statistical calculation but demands a new socio-economic paradigm in which poverty is focused upon in terms of its historical, social, cultural and economic dimensions and which takes into account. The new modes of production and their impact on old modes of production, the nature of shifting of the control of resources, the degree of participation of the local in modern development and industrial productivity and their representation in the industrial work force are some important aspects, which needs fresh attention. This will certainly reveal the complex nature of poverty and deprivation in region and also the need to tackle it through a multi-pronged approach.

Poverty as a complex and multidimensional problems have close association with the geography of region, strategies of industrial development at global and national levels and how it has impacted the local people. The study area (Vindhayan region) comes in the category of high productivity (forestry), having 6-9
$\mathrm{M}^{3}$ wood per hectare per year (Sagreiya, 1979). But due to development of industries and construction of dams a sizeable proportion of forest has disappeared and accentuated the problem of eco- degradation and marginalization. The first cement factory was established in 1951 at Churk north of river Sone. Later on a new one came up at Dala in 1972.The production of aluminium was started in 1962 with the formation of Hindustan Aluminium Corporation (HINDALCO) by the Birla Group (India) and the Kaiser (U.S.A.). To meet the requirements of HINDALCO, the Kanoria chemicals were constructed in 1964, and started manufacture caustic soda, liquid chlorine, hydrochloric acid, stable bleaching powder (SBP) and benzene hexa-chloride (BHC), which has changed the spatial dynamics of the area. The increasing demand of power to boost the industrialization, policy makers tried to build new dams and reservoirs for utilizing prevailing resource potential in power generation. The river Rihand which has a total catchment area of 13,328 sq. $\mathrm{km}$ with annual average rainfall precipitation of142 $\mathrm{cm}$ was used for reservoir and dam. Due to this, the good fertile land of Singrauli basin was submerged into 469 sq. km. of reservoir.

Consequently, large proportions of population were displaced from their native land, livelihood and environment and were marginalized in the process of industrialization and modernization. The Obra-Rihand Power complex is another industrial project which consists of both thermal and hydro power generation plants. It generates about 50 per cent of electricity requirements of Uttar Pradesh. This complex comprises three units i.e. Obra Thermal Power Plants (in 1964), Obra Hydro-Power Plant (construction started in 1964) and Rihand-Hydro Power Plant (construction started in 1954 and completed in 1962). Since 1959 Obra has been 'Nachiragi' (zero population land) and lies in Robertsganj Tahsil in south Mirzapur district (now District of Sonbhdra) of Uttar Pradesh.

This Obra-Rihand Power Complex provides electricity to Eastern Uttar Pradesh, Bihar, and Madhya Pradesh. Besides this, several other power projects have been established in the area and this has changed the natural physiographic and social character of the landscape. The Anpara Thermal Power plant was constructed in 1979-88 under the joint collabora- 
tion of Government of India and Government of Japan with a total cost of Rs 3 billion with a projected capacity of 3130MW.The Renusagar Thermal Power Plant with the capacity of $270 \mathrm{MW}$ was launched by HINDALCO. The National Thermal Power Corporation (NTPC) selected the area of Rihand river bank nearer to reservoir for the establishment of Super Thermal Power. It has capacity of $2000 \mathrm{MW}$. Besides this, the NTPC has constructed another thermal power plant at Bijpur. The Singrauli Power Complex has emerged as a significant power generation centre in India.

The above mentioned industrial projects have adversely affected major impact on the social environment of the local tribal population. After independence, the geographical location and resource base of the area have attracted policy-makers and industrialists to modernize and industrialize the region but they were not driven by any altruistic or egalitarian motives. Their sole purpose was to exploit the available resources of the area for optimizing their profits and satisfy their greed. The Environmental Impact Assessment (EIA) of the region reveals various evils which have emerged as fallout of modernization and development and among these the general poverty of the reason is the most obvious. Any impartial inquiry would bring this out. Initially study area was characterized by a remote geographical identity with rough terrain. But the input for development-capital, skilled labour, and technologyhave changed the social and economic organization of area. This has led to spatial conflict, problems of development induced displacement and deprivation from land, livelihood and nature. Industrialization of the area has ironically enough, has taken away so much from the local and given precious little in return. Poverty was a phenomenon earlier also but the bounty of nature was there to obviate it to some extent. Industrialization should have been a boon to the people but it has only accentuated their misery by pushing them out of its bounds and depriving them of their traditional sources of sustenance and livelihood. True industrial development should not be wished away but what needs to be remembered is that the local people should be the first beneficiaries of its dividends. What has happened is the exact-opposite.

\section{CONCLUSION}

In view of the above discussion on various aspects of geography, poverty and development the author came to conclusion that the uneven patterns of development in different geographical locations have multiple effects on society, economy and individual. The prevalence of poverty in a region is the outcome of an interrelated phenomenon of identity of geographical space, dynamics of development strategies and cumulative effects of the history of changes in the mode of production and its overall impact on land, livelihood and society. Regarding poverty in the Vindhyan region (study area) the following points have emerged in the course of the present study:

The uneven pattern (in terms of terrain, climate, soil condition and other geographical components, economic and social development, level of human development etc.) of a geographical location play a major role in shaping the economic development of individual and society. Development, with its goal and strategies, is a powerful agency in the transformation of a backward society and space into vibrant, dynamic and diversified fast moving living objects and also promotes new spatial dynamics. The emergence of new spatial dynamics challenges before primitive and unskilled inhabitants of the region and leads to the process of alienation from ongoing development and industrialization they find it difficult to adjust to the changed mode of production. Development induced displacement occurs, depriving the people of their land, livelihood and other resources. And these processes have accentuated the extent and magnitude of poverty.

\section{REFERENCES}

KUMAR, C. S. Environmental problems and development: a geographical study. Ganga kaveri publishing house. Varanasi. 1998, p. 91-124.

COX, K.; REYNOLDS D. R. Locational approach to power and conflict, In: COX, K; REYNOLDS, D. R. (Eds.). Locational approach to power and conflict. New York. 1974. p. 19-42. 
DESHPANDE, V.N. Poverty, class and caste: Some conceptual and methodological issues in social science research and problems of poverty. Taralok Singh (Eds.). Concept publishing company. New Delhi. 1990. 133 p.

GRAMSCI, A. Selection from the Prison Notebooks. New York International Publishers, 1971. p. 285-286.

HARTSHORNE, R. The Nature of Geography: A critical survey of current thought in the light of past. Association of American Geographers and thoughts by Richard Peet in Modern Geographical Thought' Blackwell Publishers, U.S.A, 1932. 16 p.

JAMES, P.E. Toward a further understanding of the regional concept, Annals of the Association of American Geographers, v. 42, 1952. p. 197-198.

MARX, K. The British Rule in India. In: MARX, K. ENGELS, F.: Collected Works, v.12, Progress Publishers: Moscow. 1979. 13 p.
KURIEN, C.T. Poverty, planning and social transformation. Allied Publishers: New Delhi. 1982. 18 p.

MISHRA, A.P. Development and displacement: Changing dynamics of spatial economy in India. Questioned Geographical, 27 B/1, Adam Mickiewicz University Press, Poznan. 2008. p. 93-103.

SAGREIYA, K.P. Forest and Forestry. National Book Trust of India. New Delhi. 1979. p. 174-194.

SANTOS, M. Society and Space: Social formation as theory and method. Antipode, v 9. 1977. 5 p.

SOJA, E. W. The socio-spatial dialectics. Annals of the Association of American Geographers, v. 70, $\mathrm{n}$. 2, p. 207-25, jun. 1980

VOLKOV, M. L. A dictionary of political economy. Progress Publishers: Moscow. 1985. p. 14-15. 